\title{
LONG-TeRm SURVEILLANCE PLAN For The South Clive Disposal Site, Clive, Utah
}

March 1996

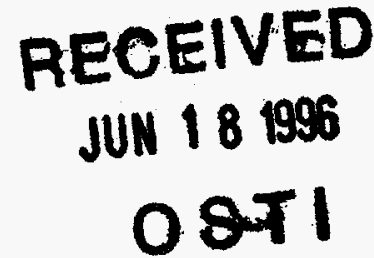

\section{DISCLAIMER}

This report was prepared as an account of work sponsored by an agency of the United States Government. Neither the United States Government nor any agency thereof, nor any of their employees, makes any warranty, express or implied, or assumes any legal liability or responsibility for the accuracy, completeness, or usefulness of any information, apparatus, product, or process disclosed, or represents that its use would not infringe privately owned rights. Reference herein to any specific commercial product, process, or service by trade name, trademark, manufacturer, or otherwise does not necessarily constitute or imply its endorsement, recommendation, or favoring by the United States Government or any agency thereof. The views and opinions of authors expressed herein do not necessarily state or reflect those of the United States Government or any agency thereof.

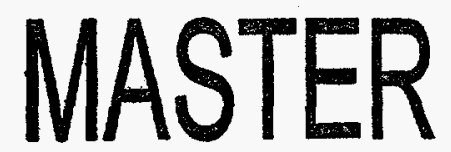


This report has been reproduced from the best available copy. Available in paper copy and microfiche

Number of pages in this report: 44

DOE and DOE contractors can obtain copies of this report from:

Office of Scientific and Technical Information

P.O. Box 62

Oak Ridge, TN 37831

(615) 576-8401

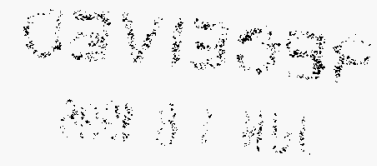

This report is publicly available from:

National Technical Information Service Department of Commerce 5285 Port Royal Road Springfield, VA 22161 (703) $487-4650$ 


\section{DISCLAIMER}

Portions of this document may be illegible in electronic image products. Images are produced from the best available original document. 


\section{LONG-TERM SURVEILLANCE PLAN FOR THE}

SOUTH CLIVE DISPOSAL SITE

CLIVE, UTAH

March 1996

Prepared for

U.S. Department of Energy

Environmental Restoration Division

UMTRA Project Team

Albuquerque, New Mexico

Prepared by

Jacobs Engineering Group Inc.

Albuquerque, New Mexico 



\section{TABLE OF CONTENTS}

\section{Section}

Page

1.0 PURPOSE AND SCOPE.

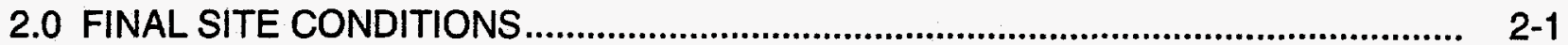

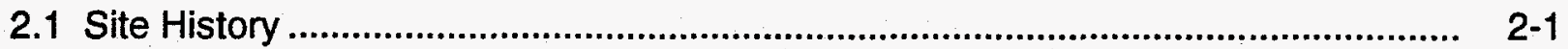

2.2 General description of the site vicinity ............................................................. $2-1$

2.3 Disposal site description ........................................................................................ $2-3$

2.3.1 Site ownership and legal description ................................................................ 2-3

2.3.2 Directions to the disposal site............................................................................. $2-3$

2.3.3 Description of surface conditions ....................................................................... $2-4$

2.3.4 Permanent site-surveillance features ................................................................ $2-4$

2.4 Disposal cell design ............................................................................................. $2-5$

2.5 Ground water characterization .............................................................................. $2-5$

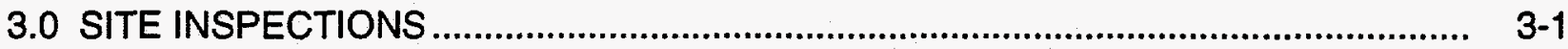

3.1 Inspection frequency ................................................................................... $3-1$

3.2 Inspection team ........................................................................................................ $\quad 3-1$

3.3 Site inspection procedures ………........................................................................... $\quad 3-1$

3.4 Follow-up inspections ..................................................................................... $3-2$

3.5 Quality assurance ................................................................................................... $\quad 3-3$

3.6 Site inspection documentation .............................................................................. $\quad 3-3$

3.6.1 Site inspection checklist ................................................................................. $3-3$

3.6.2 Site inspection maps...................................................................................... $3-3$

3.6.3 Site inspection photographs ........................................................................... $3-4$

3.6.4 Field notes ................................................................................................... $3-4$

3.6.5 Site inspection report ............................................................................... $\quad 3-4$

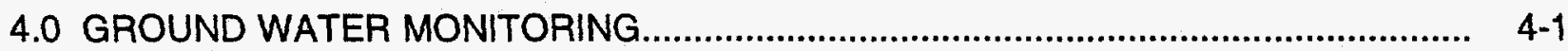

5.0 CUSTODIAL MAINTENANCE OR REPAIR …................................................... 5 -1

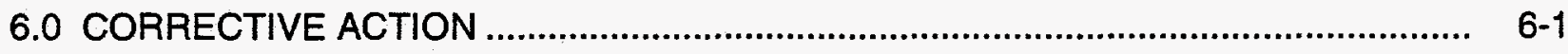

7.0 EMERGENCY NOTIFICATION AND RESPONSE ......................................................

8.0 RECORD KEEPING AND REPORTING ................................................................ 8-1

9.0 LIST OF CONTRIBUTORS .................................................................................... 9

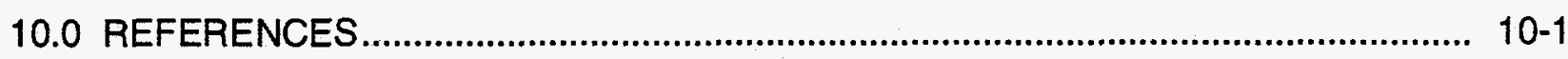

$\begin{array}{ll}\text { ATTACHMENT } 1 & \text { SITE REAL ESTATE INFORMATION } \\ \text { ATTACHMENT } 2 & \text { NRC CONCURAENCE WITH SURFACE PROJECT GROUND WATER } \\ & \text { PROTECTION STRATEGY } \\ \text { ATTACHMENT } 3 & \text { AGENCY NOTIFICATION AGREEMENTS }\end{array}$




\section{LIST OF FIGURES}

\section{Fiqure}

Page

2-1 South Clive disposal site and Salt Lake City processing site locations.

\section{LIST OF PLATES}

\section{Plate}

1 Disposal site baseline map, South Clive, Utah, site 


\section{LIST OF ACRONYMS}

Acronym

DOE

EIS

EPA

LTSP

NRC

RAP

RRM

UMTRA

UMTRCA

\section{Definition}

U.S. Department of Energy

environmental impact statement

U.S. Environmental Protection Agency

long-term surveillance plan

U.S. Nuclear Regulatory Commission

remedial action plan

residual radioactive material

Uranium Mill Tailings Remedial Action

Uranium Mill Tailings Radiation Control Act 



\subsection{PURPOSE AND SCOPE}

This long-term surveillance plan (LTSP) describes the U.S. Department of Energy's (DOE) long-term care program for the Uranium Mill Tailings Remedial Action (UMTRA) Project South Clive disposal site in Clive, Utah.

The U.S. Nuclear Regulatory Commission (NRC) has developed regulations for the issuance of a general license for the custody and long-term care of UMTRA Project disposal sites in 10 CFR Part 40. The purpose of this general license is to ensure that the UMTRA Project disposal sites will be cared for in a manner that protects the public health and safety and the environment. For each disposal site to be licensed, the NRC requires the DOE to submit a site-specific LTSP. The DOE prepared this LTSP to meet this requirement for the South Clive disposal site. The general license becomes effective when the NRC concurs with the DOE's determination of completion of remedial action for the South Clive site and the NRC formally accepts this LTSP.

This LTSP describes the long-term surveillance program the DOE will implement to ensure that the South Clive disposal site performs as designed. The program's primary activity is site inspections to identify threats to disposal cell integrity. Ground water monitoring is not necessary to demonstrate disposal cell performance and will not be conducted because of the application of supplemental standards based on the limited use of background ground water in the uppermost aquifer. The LTSP is based on the Guidance for Implementing the Long-Term Surveillance Program for UMTRA Project Title I Disposal Sites (DOE, 1996) and meets the requirements of 10 CFR $\S 40.27$ (b) and 40 CFR $\S 192.03$. 



\subsection{FINAL SITE CONDITIONS}

Remedial action at the former Salt Lake City, Utah, uranium mill tailings processing site consisted of excavating and relocating the residual radioactive materials (RRM) to the South Clive disposal site. The DOE constructed a disposal cell to control the RRM in accordance with 40 CFR Part 192. The South Clive disposal site is fenced, and its perimeter is marked with warning signs. The site completion report (MK-F, 1996) contains a detailed description of the final site conditions.

\subsection{SITE HISTORY}

Vitro Chemical acquired a plant built to produce alumina from alunite and converted the plant to process uranium ore from 1951 to 1964 . From 1964 to 1968 , the mill produced vanadium. Plant demolition began in 1968 and was complete in 1970.

When the plant was dismantled, the approximately 1.6 million cubic yards $\left(y d s^{3}\right)$ ( 1.2 million cubic meters $\left[\mathrm{m}^{3}\right]$ ) of radioactively contaminated materials and over $850,000 \mathrm{yds}^{3}\left(650,000 \mathrm{~m}^{3}\right)$ of other contaminated material remained on the site. Approximately $2,798,000 \mathrm{yds}^{3}\left(2,140,000 \mathrm{~m}^{3}\right)$ of RRM were moved from the former Vitro Processing site and vicinity properties in South Salt Lake City, Utah, and transported and stabilized in the South Clive disposal site. Remedial action was performed by the state of Utah under the direction of the DOE UMTRA Project Team. Remedial action began in 1984 and was completed in 1988.

The DOE evaluated the environmental impacts associated with the Salt Lake City processing site remedial action in an environmental impact statement (EIS) (DOE, 1984a). The NRC and the state of Utah concurred with the DOE's remedial action plan (RAP) to comply with the requirements of 40 CFR Part 192, Subparts A-C (Attachment 2). The DOE prepared a completion report documenting compliance with the remedial action plan (MK-F, 1996).

\subsection{GENERAL DESCRIPTION OF THE SITE VICINITY}

The South Clive disposal site is in Tooele County, Utah, approximately 81 miles (mi) (130 kilometers [km]) west of Salt Lake City in Township 1 South, Range 11 West, Section 32 (Figure 2-1). This section briefly describes the site vicinity. Detailed descriptions can be found in the site EIS (DOE, 1984a) and the site RAP (DOE, 1984b). 


\section{Figure 2.1}

South Clive Disposal Site and

Salt Lake City Processing Site Locations

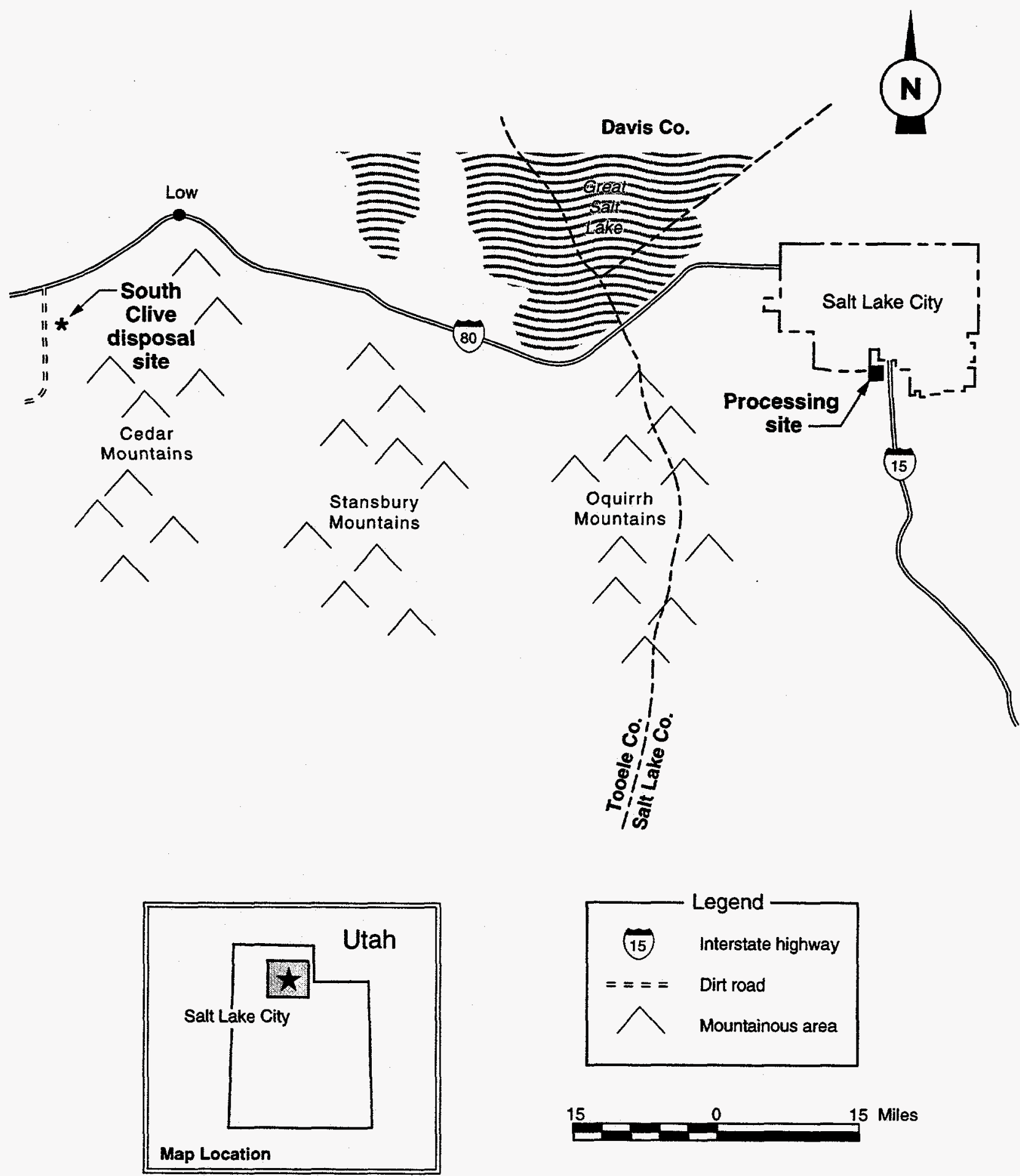


The site is located in a flat area along the east edge of the Great Salt Lake Desert, which extends approximately $60 \mathrm{mi}(100 \mathrm{~km})$ from the Nevada/Utah border on the west to a series of north trending mountain ranges on the east. East of the site, the Cedar Mountains rise to elevations of approximately 7700 feet (ft) (2300 meters [m]) above sea level. The proximity of this mountain range causes surface drainage to flow west toward the site.

\section{$2.3 \quad$ DISPOSAL SITE DESCRIPTION}

This section describes the disposal site. Detailed descriptions can be found in the site RAP (DOE, 1994b) and the site completion report (MK-F, 1996).

\subsubsection{Site ownership and legal description}

The state of Utah currently holds title to the South Clive disposal site. Attachment 1 provides a legal description of the disposal site and will document the transfer of title of the disposal cell to the DOE for long-term care. Plate 1 shows the final site boundary and identifies ownership of the site and surrounding areas at the time of licensing.

\subsubsection{Directions to the disposal site}

The South Clive disposal site can be accessed by following these directions:

1. Travel west on Interstate-80 out of Salt Lake City.

2. Take Clive exit (Exit 49).

3. Turn south at the top of the off-ramp and continue onto the paved road that becomes an all-weather dirt road at mile marker 69.0.

4. Cross double track of the Westem Pacific Railroad and continue south on the road to Envirocare. (The road to the southwest is the route to a waste incinerator facility operated by the U.S. Pollution Control, Inc.)

5. Turn east at the fork in the road and follow the sign to Envirocare.

6. Drive to the entrance gate at the northwest end of the site. Envirocare's administration building is to the north, and the state of Utah Site Radiation Control Office is in a trailer north of the Envirocare building.

The south access gate is kept locked, and the key needed to enter the site may be obtained from the DOE. 


\subsubsection{Description of surface conditions}

The completed South Clive disposal cell occupies approximately 54 acres (ac) (22 hectares [ha]) of its nearly 100-ac (40-ha) rectangular-shaped site. The disposal cell is surrounded by a toe drain, a maintenance road, and a perimeter diversion channel (Plate 1). The site is enclosed by a locked gate and fence, and the perimeter is marked with warning signs, boundary markers, and survey monuments (Section 2.3.4). The completion report contains a detailed description of the final site conditions.

The DOE studied, tested, and documented final disposal site conditions with site maps, calculations, and as-built section drawings. This information, included in the appendix of the completion report (MK-F, 1996) illustrates baseline conditions for comparison to future disposal site conditions. All original drawings, site maps, and photographs are part of the South Clive disposal cell permanent site file.

\subsubsection{Permanent site-surveillance features}

Survey and boundary monuments, site markers, and waming signs are the permanent long-term surveillance features of the South Clive disposal site. Plate 1 shows the locations of these features. Typical construction and installation specifications for these features are shown in the Guidance for Implementing the Long-Term Surveillance Program for UMTRA Project Title I Disposal Sites (DOE, 1996) and any subcontract documents.

Two site markers identify the South Clive disposal site, the general location of the stabilized disposal cell within the site boundaries, the date of closure (December 1988 ), the wet tonnage of tailings $(2,798,000$ tons $[2,538,000$ metric tons $])$, and the curies of radioactivity (1550 curies of radium-226).

Site marker SMK-1, inside the entrance gates to the site, is set in a bed of reinforced concrete that extends $3 \mathrm{ft}(1 \mathrm{~m})$ below surface. Site marker SMK-2, at the crest of the disposal cell, is set in a bed of reinforced concrete that extends to the top of the radon barrier. Magnets in the markers permit easier detection if they become buried over time. The survey monument identification number is stamped on the top of each monument's metal cap.

A warning sign, placed at the entrance to the disposal site, notes that trespassing is forbidden and provides the Grand Junction Project Office's 24-hour telephone number. Sixteen perimeter signs are mounted on the security fence. The warning sign and perimeter signs indicate the presence of radioactive materials, using the international symbol for radioactivity.

Nine settlement plates were placed in three rows across the top of the South Clive disposal site. Plates are located from north to south as follows: 
- SP-2NW, SP-1, and SP-10 are near the northern edge of the top transect.

- SP-3, SP-7, and SP-12 are across the middle of the transect.

- SP-11, SP-8, and SP-2SE are near the southern edge of the top transect.

The settlement plates are each marked by a section of galvanized pipe that rises approximately $1 \mathrm{ft}(.3 \mathrm{~m})$ above the rock-covered surface. Each pipe is topped by a threaded cap, and all pipes and caps are painted orange.

The perimeter warning signs are similar to those shown in the Guidance for Implementing the Long-Term Surveillance Program for UMTRA Project Title I Disposal Sites (DOE, 1996).

\subsection{DISPOSAL CELL DESIGN}

The completed disposal cell is an embankment that extends partially below grade and occupies an area approximately $1115 \mathrm{ft}(340 \mathrm{~m})$ by $2110 \mathrm{ft}(643 \mathrm{~m})$. The final covered embankment is $35 \mathrm{ft}(11 \mathrm{~m})$ above the surrounding terrain and has side slopes of 20 percent ( 1 vertical to 5 horizontal) and 2 percent top slopes. The tailings and other contaminated materials extend from approximately $9 \mathrm{ft}(3 \mathrm{~m})$ below grade to approximately $26 \mathrm{ft}(8 \mathrm{~m})$ above grade. The cell is unlined; however, the excavation subgrade was scarified and compacted before fill placement.

Contaminated materials were covered with a $7-\mathrm{ft}(2-\mathrm{m})$-thick layer of silty clay. This layer serves as a radon and infiltration barrier. The top and side slopes of the disposal cell were also covered with a $1.5-\mathrm{ft}(0.5-\mathrm{m})$-thick rock barrier and a $0.5-\mathrm{ft}$ $(0.15-\mathrm{m})$-thick sand layer to resist erosion, plant root intrusion, and burrowing animals. These aggregate layers help prevent drying of the underlying silty clay layer. Material excavated for partial below-grade disposal was used to construct the silty clay cover. The cell was designed to be protective of the environment for 1000 years, or in any case, for at least 200 years.

The disposal cell contains approximately $2,798,000 \mathrm{yds}^{3}\left(2,140,000 \mathrm{~m}^{3}\right)$ of relocated tailings and $750,000 \mathrm{yds}^{3}\left(574,000 \mathrm{~m}^{3}\right)$ of other RRM, primarily contaminated soil and demolition debris.

Detailed engineering drawings of the disposal cell are in the appendix of the site completion report (MK-F, 1996).

\subsection{GROUND WATER CHARACTERIZATION}

As part of the process to select an appropriate site for the disposal of tailings, an evaluation of background ground water quality was conducted at the South Clive site. Based on an evaluation of disposal site characterization data from 17 
monitoring wells, background ground water in the uppermost aquifer was determined to be of limited use. Limited use ground water is not currently nor potentially a source of drinking water in the area because of widespread ambient contamination that cannot be cleaned up using methods reasonably employed by a public water supply system. NRC concurrence with this is in Attachment 2 to this document. 


\subsection{SITE INSPECTIONS}

The DOE will conduct annual inspections of the South Clive disposal site to detect progressive changes caused by slow-acting natural processes and to identify potential problems before the need for extensive maintenance, repairs, or corrective action occurs. Follow-up inspections also will be conducted as needed. The DOE will compare the inspection findings to baseline conditions and previous inspection reports to identify any changes over time and to provide a basis for future inspections, repairs, and corrective actions.

Site inspections will be thoroughly documented. After each inspection, the DOE will prepare a report for the NRC that records the findings of the inspection and that clearly identifies any adverse impacts or threats to the disposal cell.

\subsection{INSPECTION FREQUENCY}

The DOE will inspect the South Clive disposal site annually. The DOE may schedule more frequent inspections at any time should the need arise. For example, the DOE may schedule a separate inspection of site vegetation if the annual site inspection did not coincide with the general growing season.

\subsection{INSPECTION TEAM}

The inspection team will consist of a minimum of two inspectors qualified to inspect disposal cell integrity and make preliminary assessments of modifying processes that could adversely affect the disposal cell. A plant specialist may also participate in inspections if vegetation at the site requires inspection.

Follow-up inspection teams will include one or more technical specialists in appropriate disciplines to assess the problem(s) under investigation. For example, a follow-up inspection by a plant specialist may be required to evaluate reports of significant plant growth on the rock cover, or a soils scientist or geomorphologist may be needed to evaluate erosion processes.

\subsection{SITE INSPECTION PROCEDURES}

The Guidance for Implementing the Long-Term Surveillance Program for UMTRA Project Title I Disposal Sites (DOE, 1996) contains information useful in preparing for inspections.

Site inspectors will inspect the disposal cell, the area surrounding the disposal cell, and the immediate off-site areas. Site inspections must be thorough enough to identify any significant changes or active modifying processes that could potentially adversely affect the disposal cell. Surveillance should be performed to identify unanticipated effects of modifying processes such as gully formation, slope erosion, 
changes to the rock cover, ephemeral drainage channel changes, and significant modifications by humans, animals, or plants.

Inspectors will evaluate the integrity of the disposal cell by walking a series of transects around the perimeter and over the rock cover. Inspectors will review transect paths from previous inspections and make efforts to vary the path of transects from one inspection to the next to ensure small anomalies are not overlooked. The sample inspection checklist provided in Guidance for Implementing the Long-Term Surveillance Program for UMTRA Project Title I Disposal Sites (DOE, 1996) lists items that should be examined during inspections.

The disposal cell has a rock cover, and there is no planned vegetation on the disposal cell. However, remedial action of the areas surrounding the disposal cell included revegetation with grasses. The area surrounding the disposal cell will be monitored to determine the success of the revegetation efforts. Inspectors also will inspect this area for evidence of erosion caused by wind, sheet wash, or changes in drainage patterns.

Site inspections also will monitor damage to or disturbance of permanent site surveillance features and fencing, gate, and locks.

From inside the disposal site, inspectors will visually survey the area within a maximum of $0.25 \mathrm{mi}(0.40 \mathrm{~km})$ from the boundary of the disposal site for evidence of land-use changes. Inspectors will note the condition of and changes to site access roads, surrounding vegetation, and relevant geomorphic features like gullies or ephemeral drainage channels; potential impacts to the site will be noted.

All site inspections will be conducted in accordance with a DOE-approved safety and health plan.

\subsection{FOLLOW-UP INSPECTIONS}

DOE will conduct follow-up inspections to investigate and quantify specific problems found during a previous inspection, other DOE-initiated activity, or other confirmed reports of vandalism, intrusion, damage, or other significant threat to the disposal site. Notifications of severe rainstorms, flash floods, or unusual events such as tornadoes or earthquakes near the South Clive site also can trigger follow-up inspections. Follow-up inspections will be conducted to determine whether processes currently active at or near the site threaten site security or stability and to evaluate the need for custodial maintenance, repair, or other corrective action. The scope of these follow-up inspections may be broad and similar in nature to site inspections or focused on specific areas of concern.

A follow-up inspection usually will begin with an on-site visit by technical specialists to confirm if the disposal cell has been damaged or to determine the need for more 
definitive tests or studies. The DOE will schedule additional site visits if more data are needed to draw conclusions and to recommend repairs or corrective action.

\subsection{QUALITY ASSURANCE}

The DOE has developed and implemented a quality assurance plan (DOE, 1992) for the site inspection program that meets the requirements of DOE Order 5700.6C. All site inspections will be conducted according to this quality assurance plan.

\subsection{SITE INSPECTION DOCUMENTATION}

During site inspections, all activities and observations will be recorded and described using a site inspection checklist, site inspection map, photographs and photo log, and field notes. Documentary evidence of anomalous, new, or unexpected conditions or situations must describe developing trends and enable the DOE to make decisions concerning follow-up inspections, custodial maintenance, and corrective action. The DOE will prepare a site inspection report documenting the findings and recommendations from each field inspection.

\subsubsection{Site inspection checklist}

The sample site inspection checklist in the Guidance for Implementing the LongTerm Surveillance Program for UMTRA Project Title I Disposal Sites (DOE, 1996) is a guide for the inspectors to prepare for and conduct site inspections. Inspectors will prepare a site-specific checklist that addresses the features to be inspected and monitored at the South Clive disposal site. All checklist items should be completed. Annotations should be made on the checklist to add more detailed information. All entries must be clearly stated and legible because the completed checklist becomes part of the permanent field record of the inspection. Upon completion of the inspection, the lead inspector must sign and date a statement certifying the scope of the inspection.

After each inspection is complete, the checklist may be revised, if necessary, to include new information or to delete items that are no longer pertinent. Revisions to the checklist will be documented in the inspection report.

\subsubsection{Site inspection maps}

Plate 1 serves as the baseline for preparing the site inspection map. The inspection team will annotate copies of the site inspection map during site inspections. The annotated site inspection map must include the following information:

- Inspection traverses.

- Photograph locations. 
- Locations and descriptions of any new, anomalous, or unexpected features.

- Features identified during previous inspections for observation or monitoring.

- Inspection date and type of inspection.

\subsubsection{Site inspection photographs}

A photographic record of the site inspection must be maintained. Site conditions should be documented by ground photographs to record developing trends and to enable the DOE to make decisions concerning additional inspections, custodial maintenance or repairs, or corrective action. If possible, any site feature or condition requiring inspectors to make a written comment, explanation, or description will be photographed. A site inspection photo log will be used to record the photographs. A separate photo log should be completed for each roll of exposed film, with an entry for each photograph.

At a minimum, the site features listed in the Guidance for Implementing the LongTerm Surveillance Program for UMTRA Project Title I Disposal Sites (DOE, 1996) should be documented with photographs during site inspections. In addition, any new or potential problem areas identified during a site inspection must be well documented with photographs. All site inspection photographs, as well as all corresponding photo log forms, will be maintained in the permanent site file.

\subsubsection{Field notes}

The inspection team will use field notes to record observations made during the inspection but not recorded on the inspection checklist or inspection map. The field notes will become part of the permanent site file.

\subsubsection{Site inspection report}

After every site inspection, the DOE will prepare a site inspection report that discusses the scope of the inspection, observations made, and conclusions drawn from the inspection. At a minimum, the inspection report will include the following:

- Description of the site conditions.

- Completed site inspection checklists and any relevant supporting documentation, including names and qualifications of the field inspectors.

- Site inspection map and other relevant drawings, maps, or figures.

- Inspection photographs and photo logs. 
- Conclusions and recommendations for follow-up inspections, custodial maintenance, or repairs, if required.

- Custodial maintenance or repair report and certification, if any was performed.

If new conditions, requiring monitoring or immediate action, are discovered during the inspection, the inspection report will detail any observed modifying features and will include a description of the problem, relevant measurements and photographs, and an impact assessment. The description of the modifying process will include information such as the following:

- Extent of area affected.

- Number, spacing, and size of features (e.g., gullies).

- Locations and patterns of occurrence.

- Species, location, and density of volunteer plant growth.

Evidence of deliberate and repeated human intrusion such as cover removal, extensive vandalism to signs and monuments, or the presence of well-established trails will be described in detail. All signs of vandalism will be noted because evidence of continued vandalism may indicate the need to implement more active measures to control site access.

The results of all follow-up inspections will be documented in written reports. Other appropriate documentation such as photographs, measurements, and drawings will be included. At a minimum, a follow-up inspection report must include the following:

- Description of the problem and preliminary assessment of impact.

- Conclusions and recommendations for custodial maintenance, repair, or corrective action required.

- Assessment data, photographs, and supporting documentation.

A copy of all site inspection reports and supporting documentation will be maintained in the permanent site file. 



\subsection{GROUND WATER MONITORING}

The DOE evaluated the need for ground water monitoring at the South Clive disposal site in accordance with the licensing regulations at $10 \mathrm{CFR} \$ 40.27(\mathrm{~b})(2)$ and the ground water protection standards at 40 CFR Part 192, Subparts A and C. The disposal design was based on standards that were subsequently remanded, in part, on September 3,1985 . The U.S. Environmental Protection Agency (EPA) considered these sites separately when publishing the final rule (60 FR 2854); and stated "this site also qualifies for a supplemental standard under 40 CFR $\$ 192.21(\mathrm{~g})$, and modification of the existing disposal cell is not warranted."

Ground water monitoring is not required at the South Clive disposal site because tailings from the mill are stabilized over ground water that contains dissolved solids in excess of 10,000 milligrams per liter and the disposal site is not contributing to contamination of any currently or potentially useful aquifer. Under these circumstances this site qualifies for supplemental standards (60 FR 2863). 


\subsection{CUSTODIAL MAINTENANCE OR REPAIR}

The DOE does not plan to conduct routine maintenance at the South Clive disposal site. However, the DOE will perform needed custodial maintenance or repair as determined from site inspections. The DOE will prepare a statement of work, which will include qualifications of the maintenance/repair contractor, and certify all custodial maintenance and repair work performed at the South Clive disposal site.

Unscheduled custodial maintenance or repair required at the South Clive disposal site may include the following:

- Repairing or replacing deteriorated or vandalized warning signs, fencing, gate, and locks.

- Removing volunteer plant growth from riprap-covered areas.

- Reseeding areas surrounding the disposal cell.

If repairs are needed to address problems that may affect the integrity of the disposal cell or compliance with 40 CFR Part 192, the NRC must approve the recommended action in advance. Such action will be treated as a corrective action (see Section 6.0).

After the work is completed, the maintenance/repair contractor must submit written verification of the completed work. The DOE will inspect the site, as necessary, and review the report before certifying that all work is completed according to all required specifications.

The annual report to the NRC must include the following information on unscheduled maintenance or repair:

- Work order, purchase order, or statement of work.

- Contractor documentation of work completion.

- DOE certification of work completion.

Copies of all records, reports, and certifications will be included in the permanent site file. 



\subsection{CORRECTIVE ACTION}

Site inspections are designed to identify problems at the developmental stage. Examples of conditions that might trigger corrective action are

- Surface rupture or subsidence of the disposal cell.

- Development of rills or gullies or slope instability on the disposal cell.

- Deterioration of the erosion protection rock on the disposal cell.

- Seepage originating from the disposal cell.

- Gully development on or immediately next to disposal site property that could affect the integrity of the disposal cell.

- Damage to the cell cover or disposal site property from natural catastrophic events or vandalism.

- Damage to the disposal cell cover from deep-rooted plant growth.

The DOE will evaluate the factors that caused the problem and identify actions to mitigate the impact and prevent recurrence. An on-site inspection or preliminary assessment would include, but not be limited to, the following:

- Identifying the nature and extent of the problem.

- Reevaluating germane engineering design parameters.

When a potential problem is identified, the DOE will submit a preliminary assessment report to the NRC for review no more than 60 days after the problem is identified. The preliminary assessment report will evaluate the problem and recommend the next step (e.g., immediate action or continued evaluation). After the NRC reviews the report and recommendations, the DOE will develop a corrective action plan for NRC approval. Once the NRC approves the corrective action, the DOE will implement the plan. In some cases, corrective action could include temporary emergency measures taken before the completion of the normal approval process.

NRC regulations do not stipulate a time frame for implementing corrective action.

In addition to the preliminary assessment report, the DOE may prepare progress reports on each corrective action while it is under way or under evaluation. 
After corrective action is complete, the DOE will certify all work and submit a certification statement and supporting documentation to the NRC for review and concurrence. A copy of the certification statement will become part of the permanent site file, as will all reports, data, and documentation generated during the corrective action. 


\subsection{EMERGENCY NOTIFICATION AND RESPONSE}

To ensure the timely investigation of potential problems affecting the disposal cell, the DOE has requested notification from federal, state, and local agencies of discoveries or reports of any purposeful intrusion or damage at the disposal site as well as the occurrence of earthquakes, tornadoes, or floods in the disposal site area.

The DOE negotiated notification agreements with the Tooele County Sheriff's Office, the U.S. Geological Survey's National Earthquake Information Center, and the Utah area office of the National Weather Service (Attachment 3). These agreements will provide for the DOE to be notified of the more probable occurrences that could cause an emergency response. In addition, the DOE 24-hour phone number is posted on the site entrance sign so the public can notify the DOE if problems are discovered.

The nature of the occurrence and the amount of first-hand knowledge available will determine the DOE's response. If an emergency poses an immediate threat to the public, the DOE will notify individuals who may be affected and appropriate federal, state, and local agencies, including the NRC. The DOE will take appropriate response action and advise the affected individuals of precautions that should be taken.

In all cases, the notification, response, and any follow-up activities will be documented. This documentation will become part of the permanent site file. Discussions of emergency notifications and responses also will be included in the annual site report to the NRC. 


\subsection{RECORD KEEPING AND REPORTING}

The DOE will maintain a permanent site file containing site inspection reports and other supporting documentation of long-term surveillance program activities. The information placed in the site file will include:

- Documentation of disposal site performance.

- Demonstration that licensing provisions were met.

- Information needed to forecast future site surveillance and monitoring needs.

- Reports to stakeholders regarding disposal cell integrity.

After the site is brought under the general license, the DOE will compile copies of site documentation required by the Guidance for Implementing the Long-Term Surveillance Program for UMTRA Project Title I Disposal Sites (DOE, 1996) for the South Clive disposal site permanent site file. Copies of all deeds, custody agreements, and other property documents will be kept in the site file.

The surveillance and maintenance documentation identified in other sections of this LTSP will be maintained by the DOE and become part of the permanent site file. The DOE will update the site file as necessary after disposal site inspections, maintenance activities, or corrective actions are complete. These records will be handled in accordance with DOE directives to ensure their proper handling, maintenance, and disposition. The archival procedures set forth in 41 CFR Part 101 and 36 CFR Parts 1220-1238 (Subchapter B) will be followed. All information will be available for NRC and public review.

The DOE will prepare an annual report documenting the results of site inspections and any other activities conducted in conjunction with the long-term surveillance program (Section 3.6.5). In accordance with 10 CFR Part 40 requirements, the annual report will be submitted to the NRC no more than 90 days after the date of the last UMTRA Project site inspection for that calendar year. This submittal will also include reports on any follow-up inspections and custodial maintenance or repairs performed during the year.

Following any inspection where unusual damage or disruption is discovered at the South Clive disposal site, a preliminary report assessing the impact must be submitted to the NRC within 60 days of the initial discovery of the problem. If maintenance or repair or corrective action is warranted, the DOE will notify the NRC. The NRC will receive a copy of corrective action plans and each corrective action progress report, or the reports will be attached to the annual report.

In addition to the annual inspection report, every 5 years the DOE will submit an evaluation report to the NRC. 
The DOE will provide copies of inspection reports and other reports generated under the longterm surveillance program to the state of Utah as directed in their cooperative agreement with the DOE. 


\subsection{LIST OF CONTRIBUTORS}

The following individuals contributed to the preparation of this report.

\begin{tabular}{ll}
\hline Name & Contribution \\
\hline S. Wright & Site manager, document review \\
M. Gawthrop Cooper & Document compilation and coordination \\
J. Lommler & Site Engineer \\
B. Smith & Hydrogeology \\
P. Martinez & Real estate \\
J. Crain, R. Neri Zagal, J. Lommler & Document review \\
J. Jones & Technical editing \\
L. Sanchez & Word processing \\
E. Bond, K. DeGruyter & Graphic design \\
\hline
\end{tabular}




\subsection{REFERENCES}

DOE (U.S. Department of Energy), 1996. Guidance for Implementing the Long-Term Surveillance Program for UMTRA Project Title I Disposal Sites, DOE/AL-62350-189, Rev. 0, prepared for the U.S. Department of Energy, Environmental Restoration Division, UMTRA Project Team, Albuquerque, New Mexico.

DOE (U.S. Department of Energy), 1984a. Final Environmental Impact Statement of Remedial Actions at the Former Vitro Chemical Company Site South Salt Lake, Salt Lake County, DOE/EIS-0099-F, prepared by the U.S. Department of Energy, UMTRA Project Office, Albuquerque Operations Office, Albuquerque, New Mexico

DOE (U.S. Department of Energy), 1984b. Remedial Action Plan and Site Conceptual Design for Stabilization of the Inactive Uranium Mill Tailings Site at Salt Lake City, Utah. December 1984. UMTRA-DOE/AL-0141.0000. DOE UMTRA Project Office, Albuquerque Operations Office, Albuquerque, New Mexico

DOE (U.S. Department of Energy), 1992. Long-Term Surveillance and Maintenance Program Quality Assurance Program Plan, P-GJPO-152, prepared by Chem Nuclear Geotech, Inc., for the U.S. Department of Energy, Grand Junction Projects Office, Grand Junction, Colorado.

MK-F (Morrison Knudsen-Ferguson), 1996. Salt Lake City, Utah, Draft Completion Report, prepared by MK-F for the U.S. Department of Energy, Environmental Restoration Division, UMTRA Project Team, Albuquerque, New Mexico.

\section{CODE OF FEDERAL REGULATIONS}

10 CFR Part 40, Domestic Licensing of Source Material, U.S. Nuclear Regulatory Commission.

36 CFR Parts 1220-1238, National Archives and Records, Subchapter B - Records Management, National Archives and Records Administration.

40 CFR Part 192, Health and Environmental Protection Standards for Uranium and Thorium Mill Tailings, U.S. Environmental Protection Agency.

41 CFR Part 101, Federal Property Management Regulations, General Services Administration.

\section{DOE ORDERS}

Order 5700.6C, Quality Assurance, 21 August 1991, U.S. Department of Energy, Washington, D.C. 


\section{UNITED STATES CODE}

42 USC $§ 7901$ et seq., Uranium Mill Tailings Radiation Control Act, 8 November 1978.

\section{FEDERAL REGISTER}

60 FR 2854-2871, Groundwater Standards for Remedial Actions at Inactive Uranium Mill Processing Sites, final rule, U.S. Environmental Protection Agency, 11 January 1995. 
ATTACHMENT 1

SITE REAL ESTATE INFORMATION 



\section{SITE REAL ESTATE INFORMATION}

The Uranium Mill Tailings Radiation Control Act of 1978, as amended (UMTRCA), requires the Secretary of Energy to permanently acquire lands needed to carry out the purposes of the UMTRCA. The UMTRCA designated Salt Lake City Vitro site remedial action plan called for the relocation of the Vitro site tailings to a site located near Clive, Utah. Under the terms of the Cooperative Agreement between the state of Utah and the DOE, the state was required to acquire the Clive site. The site was acquired by the Utah Division of Environmental Health from the Utah State Land Board.

\section{LEGAL DESCRIPTION}

The legal description contained in the draft conveyance document from the state of Utah to the United States of America reads as follows:

Beginning at a point which is located 1,120.32 feet North $89^{\circ} 56^{\prime} 00^{\prime \prime}$ West along the Section line and 329.49 feet South $0^{\circ} 04^{\prime}$ 'West from the Northeast comer of Section 32 , Township 1 South, Range 11 West, Salt Lake base and Meridian, and running thence North $89^{\circ} 56^{\prime} 32^{\prime \prime}$ West $1,503.72$ feet; thence South $0^{\circ} 03^{\prime} 28^{\prime \prime}$ West $2,880.50$ feet; thence South $89^{\circ} 56^{\prime} 32^{\prime \prime}$ East 1,503.72 feet; thence North $0^{\circ} 03^{\prime} 28^{\prime \prime}$ East 2,880.50 feet to the point of beginning containing 99.4368 acres.

The finalized recordation information will be supplied by the state of Utah upon recording of the conveyance documentation.

Filed: Date at Deed Book No. , on Page County. Utah.

\section{Repository}

Real estate correspondence and related documents are maintained and filed by the Property Management Branch, Property and Administrative Services Division, Albuquerque Operations Office, P. O. Box 5400, Albuquerque, NM 87115, (505) 845-6450. 



\section{ATTACHMENT 2}

NRC CONCURRENCE WITH SURFACE PROJECT GROUND WATER PROTECTION STRATEGY 

This documentation will be provided after a copy is received by the U.S. Department of Energy (DOE) from the U.S. Nuclear Regulatory Commission (NRC). 

ATTACHMENT 3

AGENCY NOTIFICATION AGREEMENTS 



\title{
DRAFT
}

Mr. Frank Scharmann

Tooele County Sheriff

47 South Main

Tooele, Utah 84074

Dear Mr. Scharmann:

The U.S. Department of Energy (DOE) Uranium Mill Tailings Remedial Action Project Team is requesting notification in the event of any unusual activities or events in Tooele County, Utah, or around the South Clive disposal site located 70 miles (113 kilometers) west of Salt Lake City, Utah.

The purpose of the notification request is to assist the DOE in surveying and maintaining the integrity of its disposal site and to ensure public safety.

If during the course of routine activities, anything out of the ordinary is observed by your staff or reported to your office, we would appreciate notification to the DOE Grand Junction Projects Office's 24-hour phone line at (970) 248-6070. If the notification request discussed above is agreeable to you, please sign and return the attached reply letter for our records as soon as possible.

Should you have any questions, please contact me at (505) 845-5668. Thank you for your attention in this matter.

\author{
Sharon Arp \\ Project Site Manager \\ Environmental Restoration Division \\ U.S. Department of Energy
}

Enclosure

cc: w/o enclosure

SHamp (ERD)

CJones (GJPO)

MHansen (TAC)

CSaumur (TAC)

JVirgona (GJPO)

SWright (TAC) 


\section{DRAFT}

Sharon Arp

Project Site Manager

Environmental Restoration Division

U.S. Department of Energy

P.O. Box 5400

Albuquerque, NM 87185

Dear Mr. Arp:

This letter is to concur with the U.S. Department of Energy (DOE) request for notification as set forth in the DOE's letter. As requested in your letter, this office will contact the DOE's Grand Junction Projects Office at (970) 248-6070 if any unusual event or anomaly is observed or reported at the South Clive disposal site located 70 miles (113 kilometers) west of Salt Lake City, Utah.

Sincerely,

Mr. Frank Scharmann

Tooele County Sheriff

cc: SArp (ERD)

SHamp (ERD)

CJones (GJPO)

MHansen (TAC)

CSaumur (TAC)

JVirgona (GJPO)

SWright (TAC) 


\section{DRAFT}

Mr. William Alder

National Weather Service

2242 West North Temple

Salt Lake City, Utah 84116

Dear Mr. Alder:

The U.S. Department of Energy (DOE) Uranium Mill Tailings Remedial Action Project Team is requesting notification in the event of issuance of flash flood or tornado warnings in Tooele County, Utah. We would appreciate notification to the DOE Grand Junction Projects Office's 24-hour phone line at (970) 248-6070 within 8 hours of issuance of a warning or episode of warnings.

The purpose of this warning is to assist the DOE in surveying and maintaining the integrity of its South Clive disposal site located 70 miles (113 kilometers) west of Salt Lake City, Utah.

If the notification request discussed above is agreeable to you, please sign and return the enclosed reply letter for our records as soon as possible.

Should you have any questions, please contact me at (505) 845-5668.

Sincerely,

Sharon Arp

Project Site Manager

Environmental Restoration Division

U.S. Department of Energy

Enclosure

cc: w/o enclosure

SHamp (ERD)

CJones (GJPO)

MHansen (TAC)

CSaumur (TAC)

JVirgona (TAC)

SWright (TAC) 


\section{DRAFT}

Sharon Arp

Project Site Manager

Environmental Restoration Division

U.S. Department of Energy

P.O. Box 5400

Albuquerque, New Mexico 87185

Dear Mr. Arp:

This letter is to concur with the U.S. Department of Energy (DOE) request for notification as set forth in the DOE's letter. As requested in your letter, this office will contact the Grand Junction Projects Office at (970) 248-6070 in the event of issuance of a flash flood or tornado warning in Tooele County, Utah.

Sincerely,

Mr. William Alder

National Weather Service

cc: SArp (ERD)

SHamp (ERD)

CJones (GJPO)

MHansen (TAC)

CSaumur (TAC)

JVirgona (GJPO)

SWright (TAC) 


\section{DRAFT}

Ms. Lorayne Frank

Utah Comprehensive Emergency Management

1110 State Office Building

Salt Lake City, Utah 84119

Dear Ms. Frank:

The U.S. Department of Energy (DOE) Uranium Mill Tailings Remedial Action Project Team is requesting notification in the event of any unusual activities or events in Tooele County, Utah, or around the South Clive disposal site located 70 miles (113 kilometers) west of Salt Lake City, Utah.

The purpose of the notification request is to assist the DOE in surveying and maintaining the integrity of its disposal site and to ensure public safety.

If during the course of routine activities, anything out of the ordinary is observed by your staff or reported to your office, we would appreciate notification to the DOE Grand Junction Projects Office's 24-hour phone line at (970) 248-6070. If the notification request discussed above is agreeable to you, please sign and return the attached reply letter for our records as soon as possible.

Should you have any questions, please contact me at (505) 845-5668. Thank you for your attention in this matter.

Sharon Arp

Project Site Manager

Environmental Restoration Division

U.S. Department of Energy

Enclosure

cc: w/o enclosure

SHamp (ERD)

CJones (GJPO)

MHansen (TAC)

CSaumur (TAC)

JVirgona (GJPO)

SWright (TAC) 


\section{DRAFT}

Sharon Arp

Project Site Manager

Environmental Restoration Division

U.S. Department of Energy

P.O. Box 5400

Albuquerque, NM 87185

Dear Mr. Arp:

This letter is to concur with the U.S. Department of Energy (DOE) request for notification as set forth in the DOE's letter. As requested in your letter, this office will contact the DOE's Grand Junction Projects Office at (970) 248-6070 if any unusual event or anomaly is observed or reported at the South Clive disposal site, Salt Lake City, Utah.

Sincerely,

Mr. Frank Scharmann

Tooele County Sheriff

cc: SArp (ERD)

SHamp (ERD)

CJones (GJPO)

MHansen (TAC)

CSaumur(TAC)

JVirgona (GJPO)

SWright (TAC) 